\title{
Editorial Expression of Concern: HULC functions as an oncogene in ovarian carcinoma cells by negatively modulating miR-125a-3p
}

\author{
Ping $\mathrm{Chu}^{1} \cdot$ Lina $\mathrm{Xu}{ }^{1} \cdot$ Haiying Su${ }^{1}$ \\ Published online: 19 March 2021 \\ (C) University of Navarra 2021
}

Editorial Expression of Concern: $J$ Physiol Biochem 75, 163-171 (2019) https://doi.org/10.1007/s13105-019-00669-5

The Editors-in-Chief would like to alert readers that concerns have been raised regarding the data in this article. The authors did not provide raw data when requested. The journal was also unable to contact the authors' institutions. Readers are advised to interpret the details of this article with caution [1].

None of the authors responded to any correspondence from the editor or publisher about this Editorial Expression of Concern.

The online version of the original article can be found at https://doi.org/10.1007/s13105-019-00669-5.

\section{References}

1. Chu, P., Xu, L. \& Su, H. HULC functions as an oncogene in ovarian carcinoma cells by negatively modulating miR-125a-3p. J Physiol Biochem 75, 163-171 (2019). https://doi.org/10.1007/s13105-01900669-5

Publisher's note Springer Nature remains neutral with regard to jurisdictional claims in published maps and institutional affiliations.
Haiying $\mathrm{Su}$

suhaiying213@sina.com

1 Department of Gynecology, Jining No.1 People's Hospital, No.6 Jiankang Road, Jining 272011, China 